\title{
Litoricola marina sp. nov.
}

Correspondence

Jang-Cheon Cho

chojc@inha.ac.kr

\author{
Ahyoung Choi, Kiyoung Lee, Hyun-Myung Oh, Jing Feng \\ and Jang-Cheon Cho
}

Division of Biology and Ocean Sciences, Inha University, Incheon 402-751, Republic of Korea
A Gram-negative, non-pigmented, non-motile, chemoheterotrophic marine bacterium, designated strain IMCC2782 ${ }^{\top}$, was isolated from a surface seawater sample of the Yellow Sea, Korea. On the basis of $16 \mathrm{~S}$ rRNA gene sequence analysis and phenotypic and genotypic characterization, strain IMCC2782 ${ }^{\top}$ is shown to represent a novel species of the genus Litoricola. Strain IMCC2782 ${ }^{\top}$ grew at $15-37{ }^{\circ} \mathrm{C}$ and tolerated $7.5 \% \mathrm{NaCl}$. Based on $16 \mathrm{~S}$ rRNA gene sequences, strain IMCC $2782^{\top}$ was related most closely to the type strain of Litoricola lipolytica ( $97.1 \%$ similarity) but showed less than $90 \%$ similarity to the type strains of other bacterial species. The predominant fatty acids were mono-unsaturated $C_{18: 1}$ and $C_{16: 1}$. The $G+C$ content of the DNA of strain IMCC2782 ${ }^{\top}$ was 59.6 mol\%. A low level of DNA-DNA relatedness $(28.1 \%)$ together with several phenotypic characteristics, including enzyme activities, served to differentiate strain IMCC2782 ${ }^{\top}$ from the type strain of L. lipolytica. Therefore, strain IMCC2782 ${ }^{\top}$ is considered to represent a novel species of the genus Litoricola, for which the name Litoricola marina sp. nov. is proposed. The type strain is IMCC $2782^{\top}\left(=\right.$ KCTC $22683^{\top}=$ NBRC $\left.105824^{\top}\right)$.
The genus Litoricola (Kim et al., 2007) in the family Litoricolaceae (Kim et al., 2007), order Oceanospirillales, comprises (at the time of writing) just one recognized species, Litoricola lipolytica. The type strain of L. lipolytica was isolated from coastal seawater of the East Sea of Korea and was characterized as Gram-negative, non-motile, chemoheterotrophic and facultatively aerobic, forming very small colonies and short rod-shaped cells. In the present study, we describe another coastal seawater strain, designated IMCC2782 ${ }^{\mathrm{T}}$, which was isolated from the Yellow Sea. Phenotypic characterization and phylogenetic analysis based on 16S rRNA gene sequences indicated that strain IMCC $2782^{\mathrm{T}}$ represents a novel species of the genus Litoricola.

Strain IMCC $2782^{\mathrm{T}}$ was isolated from a seawater sample collected from the surface (1 m depth) of the Yellow Sea (near Yeongjong Do, Incheon, Korea; $37^{\circ} 27^{\prime} 44^{\prime \prime} \mathrm{N} 126^{\circ}$ $29^{\prime} 59^{\prime \prime} \mathrm{E}$ ). A serially diluted seawater sample was spread on to oligotrophic medium, R2A agar (BD Difco), diluted $1: 10(\mathrm{v} / \mathrm{v})$ with aged seawater $(1 / 10 \mathrm{R} 2 \mathrm{~A})$, and the plates were incubated aerobically at $20{ }^{\circ} \mathrm{C}$ for 1 month. After the optimum growth temperature of the strain was determined, bacterial cultures were routinely maintained on marine agar 2216 (MA; BD Difco) or in marine broth 2216 (MB; BD Difco) at $25{ }^{\circ} \mathrm{C}$ and stored as glycerol suspensions $(20 \%, \mathrm{v} / \mathrm{v})$ at $-80{ }^{\circ} \mathrm{C}$.

The GenBank/EMBL/DDBJ accession number for the 16S rRNA gene sequence of strain IMCC2782 ${ }^{\top}$ is FJ943234.
Bacterial DNA extraction, PCR amplification and 16S rRNA gene sequencing were performed as described by Cho \& Giovannoni (2003). The almost-complete 16S rRNA gene sequence (1475 bp) of strain IMCC $2782^{\mathrm{T}}$ was aligned with its nearest relatives by using the ARB software package (Ludwig et al., 2004) and PAUP 4.0 beta (Swofford, 2002) as described by Cho \& Giovannoni (2003). Comparative sequence analyses in the ARB database were also confirmed via the EzTaxon server (Chun et al., 2007). Based on $16 \mathrm{~S}$ rRNA gene sequence comparisons, strain IMCC $2782^{\mathrm{T}}$ was shown to be related most closely to L. lipolytica KCCM $42360^{\mathrm{T}}$ ( $97.1 \%$ similarity); the novel strain did not exhibit more than $90 \%$ 16S rRNA gene sequence similarity to the type strain of any other recognized species. To investigate the phylogeny of strain IMCC2782 ${ }^{\mathrm{T}}$, 1233 nucleotide positions that could be unambiguously aligned were used to create phylogenetic trees with the neighbour-joining (Saitou \& Nei, 1987) (with the Jukes-Cantor distance formula; Jukes \& Cantor, 1969), maximum-parsimony (Fitch, 1971) and maximumlikelihood (Felsenstein, 1981) methods. The robustness of the neighbour-joining and maximum-parsimony trees was checked by bootstrap analyses based on 1000 resamplings. In all the phylogenetic trees generated in this study (Fig. 1), strain IMCC $2782^{\mathrm{T}}$ and L. lipolytica KCCM $42360^{\mathrm{T}}$ formed a robust monophyletic clade with high bootstrap support $(100 \%)$, indicating that the novel strain is a member of the genus Litoricola.

DNA-DNA relatedness, a basis for bacterial species demarcation (Wayne et al., 1987), was determined 


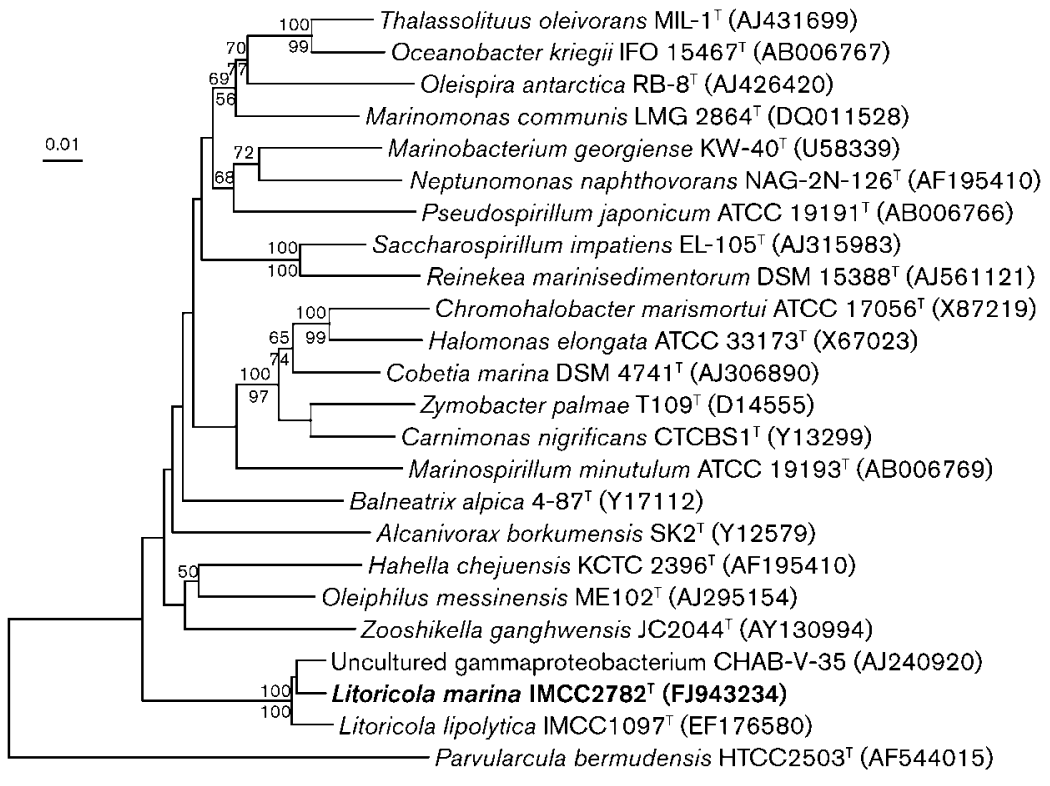

Fig. 1. Neighbour-joining phylogenetic tree, based on 16S rRNA gene sequences, showing the relationship between strain IMCC2782 $^{\top}$ and its relatives in the order Oceanospirillales. Bootstrap values (above $50 \%$ ) from both neighbour-joining (above nodes) and maximum-parsimony (below nodes) methods are presented. Nodes recovered reproducibly by all treeing methods (filled circles) or by two treeing methods (open circles) are indicated. Bar, 0.01 substitutions per nucleotide position. experimentally because the level of $16 \mathrm{~S}$ rRNA gene sequence similarity between $L$. lipolytica $\mathrm{KCCM} 42360^{\mathrm{T}}$ and strain IMCC $2782^{\mathrm{T}}$ was greater than $97.0 \%$. DNADNA hybridization was performed fluorometrically (Ezaki et al., 1989) by using photobiotin-labelled DNA probes and microdilution wells. The level of DNA-DNA relatedness between strain IMCC $2782^{\mathrm{T}}$ and L. lipolytica KCCM $42360^{\mathrm{T}}$ was $28.1 \%$ (mean from five microdilution wells), suggesting that strain IMCC $2782^{\mathrm{T}}$ should be assigned to a genomic species separate from L. lipolytica.

For phenotypic characterization, strain $\mathrm{IMCC} 2782^{\mathrm{T}}$ was routinely grown on $\mathrm{MA}$ or in $\mathrm{MB}$ at $25^{\circ} \mathrm{C}$. The temperature range for growth was determined on the basis of colony formation on MA plates incubated at 4, 10, 15, $20,25,30,37$ and $42{ }^{\circ} \mathrm{C}$. The $\mathrm{pH}$ range and optimum $\mathrm{pH}$ for growth were examined from $\mathrm{pH} 4.0$ to 12.0 (at $0.5 \mathrm{pH}$ unit intervals) in $\mathrm{MB}$ adjusted to the appropriate $\mathrm{pH}$ with $0.1 \mathrm{M} \mathrm{HCl}$ or $0.1 \mathrm{M} \mathrm{Na}_{2} \mathrm{CO}_{3}$. The range of and optimum $\mathrm{NaCl}$ concentrations for growth were determined in $\mathrm{NaCl}-$ free artificial seawater medium (Choo et al., 2007) amended with $5.0 \mathrm{~g}$ peptone, $1.0 \mathrm{~g}$ yeast extract and various concentrations of $\mathrm{NaCl}(0-15 \%, w / v)$. Cell size and morphology were determined by using phase-contrast microscopy and epifluorescence microscopy (Nikon 80i) of cells stained with 4',6-diamidino-2-phenylindole (DAPI). Colony characteristics were examined after growing aerobic cultures on MA for 1 week. Anaerobic growth was tested on MA by using the MGC anaerobic system (Mitsubishi Gas Chemical Company) for 3 weeks. Tests for catalase and oxidase were performed by assessing bubble production in $3.0 \%$ hydrogen peroxide solution and by using Kovacs' solution (Kovacs, 1956), respectively. Other biochemical tests and substrate oxidation tests were carried out by using API 20NE, API ZYM and API 50CH test strips (bioMérieux) by inoculating cells into ASW medium. For
API 20NE, API ZYM and API 50CH analyses, L. lipolytica KCCM $42360^{\mathrm{T}}$ was used as reference strain under the same culture conditions. The following antibiotics were tested by using the diffusion plate method: ampicillin $(10 \mu \mathrm{g})$, chloramphenicol $(25 \mu \mathrm{g})$, erythromycin $(15 \mu \mathrm{g})$, gentamicin $(10 \mu \mathrm{g})$, kanamycin $(30 \mu \mathrm{g})$, penicillin $\mathrm{G}(10 \mu \mathrm{g})$, rifampicin $(50 \mu \mathrm{g})$, streptomycin $(10 \mu \mathrm{g})$, tetracycline $(30 \mu \mathrm{g})$ and vancomycin $(30 \mu \mathrm{g})$.

The phenotypic characteristics of strain IMCC $2782^{\mathrm{T}}$ are given in the species description below and in Table 1. Cells of strain IMCC $2782^{\mathrm{T}}$ were Gram-negative, chemoheterotrophic, facultatively anaerobic, oxidase- and catalasepositive, non-motile, non-pigmented short rods. A number of phenotypic characteristics, including enzyme activities via the API ZYM system, could be used to differentiate strain IMCC $2782^{\mathrm{T}}$ from L. lipolytica (Table 1).

The DNA $\mathrm{G}+\mathrm{C}$ content was determined by using the HPLC method (Mesbah et al., 1989). The G $+\mathrm{C}$ content of the genomic DNA of strain IMCC $2782^{\mathrm{T}}$ was $59.6 \mathrm{~mol} \%$, only $1.7 \mathrm{~mol} \%$ different from that of L. lipolytica KCCM $42360^{\mathrm{T}}$, again suggesting that the two strains belong to the same genus. Cellular fatty acid methyl esters of strain IMCC2782 ${ }^{\mathrm{T}}$ were extracted from cultures grown on MA at $25{ }^{\circ} \mathrm{C}$ for 1 week, the same culture conditions as used for fatty acid analysis of L. lipolytica KCCM $42360^{\mathrm{T}}$. Fatty acids were analysed according to the Sherlock Microbial Identification System (MIDI).

The major cellular fatty acid constituents of strain IMCC $2782^{\mathrm{T}}$ were $\mathrm{C}_{18: 1} \omega 7 c$ and/or $\mathrm{C}_{18: 1} \omega 6 c(41.1 \%)$, $\mathrm{C}_{16: 1} \omega 7 c$ and/or $\mathrm{C}_{16: 1} \omega 6 c(29.5 \%), \mathrm{C}_{10: 0} 3-\mathrm{OH}(13.8 \%)$, $\mathrm{C}_{16: 0}(6.1 \%)$ and $\mathrm{C}_{12: 1} 3-\mathrm{OH}(5.9 \%)$, largely similar to the major fatty acid composition of L. lipolytica KCCM $42360^{\mathrm{T}}$ except for the proportions of $\mathrm{C}_{18: 1} \omega 7 \mathrm{c}$ and $\mathrm{C}_{16: 1} \omega 7 c$ (Table 2). 
Table 1. Differential characteristics between strain IMCC $2782^{\top}$ and Litoricola lipolytica $\mathrm{KCCM} 42360^{\top}$

Unless indicated, data for L. lipolytica KCCM $42360^{\mathrm{T}}$ were taken from Kim et al. (2007). +, Positive; -, negative; w, weakly positive. Cells of both strains were Gram-negative, facultatively aerobic, non-motile and oxidase-positive. In the API 20NE system, both strains were positive for $\beta$ galactosidase activity and negative for nitrate reduction, indole production, glucose fermentation, gelatin liquefaction, arginine dihydrolase and urease and gelatinase activities. In the API ZYM system, the two strains were positive for esterase lipase (C8) activity and negative for $\beta$ galactosidase, $\beta$-glucuronidase, $\alpha$-glucosidase, $\beta$-glucosidase, $N$-acetyl- $\beta$-glucosaminidase, $\alpha$-mannosidase and $\alpha$-fucosidase activities. In the API $50 \mathrm{CH}$ system, both strains were positive for acid production from glycerol, erythritol, D- and L-arabinose, D-ribose, D- and L-xylose, D-adonitol, methyl $\beta$-D-xylopyranoside, D-glucose, D-fructose, D-mannose, aesculin, ferric citrate and potassium 2-ketogluconate, weakly positive for acid production from $\mathrm{D}$-galactose and $\mathrm{D}$-arabitol and negative for acid production from inositol, methyl $\alpha$-D-mannopyranoside, methyl $\alpha$-Dglucopyranoside, $\mathrm{N}$-acetylglucosamine, amygdalin, arbutin, salicin, cellobiose, maltose, lactose, melibiose, trehalose, melezitose, raffinose, xylitol, gentiobiose, turanose and potassium 5-ketogluconate. Both strains were susceptible to chloramphenicol, erythromycin, gentamicin, kanamycin, rifampicin, streptomycin, tetracycline and vancomycin but resistant to ampicillin and penicillin $\mathrm{G}$.

\begin{tabular}{|c|c|c|}
\hline Characteristic & Strain IMCC2782 & $\begin{array}{l}\text { L. lipolytica } \\
\text { KCСM } 42360^{\mathrm{T}}\end{array}$ \\
\hline Temperature range for growth $\left({ }^{\circ} \mathrm{C}\right)$ & $15-37$ & $15-30$ \\
\hline Growth with $10 \% \mathrm{NaCl}$ & - & + \\
\hline Growth at $\mathrm{pH} 12.0$ & + & - \\
\hline Catalase & + & - \\
\hline Aesculin hydrolysis (API 20NE) & - & $+^{*}$ \\
\hline \multicolumn{3}{|l|}{ Enzyme activities (API ZYM) } \\
\hline $\begin{array}{l}\text { Alkaline phosphatase, esterase (C4), leucine arylamidase, valine arylamidase, cystine } \\
\text { arylamidase, trypsin, } \alpha \text {-chymotrypsin, acid phosphatase, naphthol-AS-BI-phosphohydrolase }\end{array}$ & + & $-{ }^{*}$ \\
\hline Lipase (C14), $\alpha$-galactosidase & $\mathrm{W}$ & $-{ }^{*}$ \\
\hline \multicolumn{3}{|l|}{ Acid production from (API 50CH): } \\
\hline L-Sorbose, sucrose, inulin, D-lyxose & + & $-{ }^{*}$ \\
\hline L-Rhamnose, dulcitol & + & $\mathrm{W}^{*}$ \\
\hline D-Mannitol, D-sorbitol, starch & $\mathrm{w}$ & $-{ }^{*}$ \\
\hline Glycogen & - & $\mathrm{w}^{*}$ \\
\hline DNA $G+C$ content $(\mathrm{mol} \%)$ & 59.6 & 57.9 \\
\hline
\end{tabular}

${ }^{*}$ Data from the present study.

Table 2. Cellular fatty acid compositions of strain IMCC $2782^{\top}$ and L. lipolytica KCCM $42360^{\top}$

Data for L. lipolytica KCCM $42360^{\mathrm{T}}$ were taken from Kim et al. (2007). The two strains were grown under the same culture conditions (on MA at $25{ }^{\circ} \mathrm{C}$ for 1 week). Values are percentages of the total fatty acids; only those components accounting for at least $1 \%$ of the total are shown. - , Not detected.

\begin{tabular}{|lcc|}
\hline Fatty acid & Strain IMCC2782 $^{\mathrm{T}}$ & $\begin{array}{c}\text { L. lipolytica } \\
\text { KCCM } \mathbf{4 2 3 6 0}^{\mathbf{T}}\end{array}$ \\
\hline $\mathrm{C}_{10: 0}$ & 1.2 & - \\
$\mathrm{C}_{16: 0}$ & 6.1 & 6.5 \\
$\mathrm{C}_{16: 1} \omega 7 c$ & $29.5^{\star}$ & $42.8 \dagger$ \\
$\mathrm{C}_{18: 1} \omega 7 c$ & $41.1 \neq$ & 20.6 \\
$\mathrm{C}_{10: 0} 3-\mathrm{OH}$ & 13.8 & 14.1 \\
$\mathrm{C}_{12: 1} 3-\mathrm{OH}$ & 5.8 & 5.6 \\
\hline
\end{tabular}

${ }^{*}$ Detected as $\mathrm{C}_{16: 1} \omega 7 c$ and/or $\mathrm{C}_{16: 1} \omega 6 c$.

$\dagger$ Detected as $\mathrm{C}_{16: 1} \omega 7 c$ and/or iso- $\mathrm{C}_{15: 0} 2-\mathrm{OH}$.

$\neq$ Detected as $\mathrm{C}_{18: 1} \omega 7 \mathrm{c}$ and/or $\mathrm{C}_{18: 1} \omega 6 c$.
Based upon the formation of a robust monophyletic clade between strain IMCC $2782^{\mathrm{T}}$ and the type strain of $L$. lipolytica and similar chemotaxonomic characteristics (including DNA G $+\mathrm{C}$ content and major cellular fatty acids), strain IMCC $2782^{\mathrm{T}}$ should be assigned to the genus Litoricola. However, the low level of DNA-DNA relatedness $(28.1 \%)$, differences in several phenotypic properties (Table 1), the low level of $16 \mathrm{~S}$ rRNA gene sequence similarity (97.1\%) (Stackebrandt \& Ebers, 2006) and the phylogenetically distinct relationship (Fig. 1) between the two strains indicate that strain IMCC $2782^{\mathrm{T}}$ represents a novel species of the genus Litoricola, for which the name Litoricola marina sp. nov. is proposed.

\section{Description of Litoricola marina sp. nov.}

Litoricola marina (ma.ri'na. L. fem. adj. marina of the sea, marine).

Cells are Gram-negative, oxidase- and catalase-positive, non-motile, non-pigmented, chemoheterotrophic and facultatively anaerobic. Grows better under aerobic than under anaerobic conditions. Cells are short rods (0.6$1.8 \times 0.3-0.7 \mu \mathrm{m})$. After 1 week of incubation on MA at 
$25{ }^{\circ} \mathrm{C}$, colonies are circular, convex, opaque, smooth, cream-coloured and $0.4 \mathrm{~mm}$ in diameter. Growth occurs at 15-37 ${ }^{\circ} \mathrm{C}$ (optimum, $25{ }^{\circ} \mathrm{C}$ ), at $\mathrm{pH} \mathrm{5.0-12.0} \mathrm{(optimum,}$ $\mathrm{pH} 8.0$ ) and in the presence of $1.0-7.5 \% \mathrm{NaCl}$ (optimum, $2.5-3.0 \% \mathrm{NaCl}$ ). Positive for $\beta$-galactosidase (API 20NE), but negative for nitrate reduction, indole production, glucose fermentation, gelatin liquefaction, arginine dihydrolase and urease and gelatinase activities. Positive for the following enzyme activities (API ZYM): esterase lipase (C8), alkaline phosphatase, esterase (C4), leucine arylamidase, valine arylamidase, cystine arylamidase, trypsin, $\alpha$ chymotrypsin, acid phosphatase and naphthol-AS-BIphosphohydrolase. Oxidizes various carbon compounds under aerobic conditions. Detailed phenotypic characteristics are given in Table 1. Major cellular fatty acids are $\mathrm{C}_{18: 1} \omega 7 c$ and/or $\mathrm{C}_{18: 1} \omega 6 c, \mathrm{C}_{16: 1} \omega 7 c$ and/or $\mathrm{C}_{16: 1} \omega 6 c$, $\mathrm{C}_{10: 0} 3-\mathrm{OH}, \mathrm{C}_{16: 0}$ and $\mathrm{C}_{12: 1} 3-\mathrm{OH}$. The DNA $\mathrm{G}+\mathrm{C}$ content of the type strain is $59.6 \mathrm{~mol} \%$.

The type strain, IMCC $2782^{\mathrm{T}}\left(=\right.$ KCTC $22683^{\mathrm{T}}=\mathrm{NBRC}$ $105824^{\mathrm{T}}$ ), was isolated from coastal seawater of the Yellow Sea, Korea.

\section{Acknowledgements}

This study was supported by the 21C Frontier Program of Microbial Genomics and Applications from the Ministry of Education, Science and Technology and by a grant from the Jung-Bu Sea Grant Program funded by the Ministry of Land, Transport and Maritime Affairs of the Korean government.

\section{References}

Cho, J.-C. \& Giovannoni, S. J. (2003). Parvularcula bermudensis gen. nov., sp. nov., a marine bacterium that forms a deep branch in the $\alpha$ Proteobacteria. Int J Syst Evol Microbiol 53, 1031-1036.

Choo, Y.-J., Lee, K., Song, J. \& Cho, J.-C. (2007). Puniceicoccus vermicola gen. nov., sp. nov., a novel marine bacterium, and description of Puniceicoccaceae fam. nov., Puniceicoccales ord. nov., Opitutaceae fam. nov., Opitutales ord. nov. and Opitutae classis nov. in the phylum 'Verrucomicrobia'. Int J Syst Evol Microbiol 57, 532-537.
Chun, J., Lee, J. H., Jung, Y., Kim, M., Kim, S., Kim, B. K. \& Lim, Y. W. (2007). EzTaxon: a web-based tool for the identification of prokaryotes based on $16 \mathrm{~S}$ ribosomal RNA gene sequences. Int J Syst Evol Microbiol 57, 2259-2261.

Ezaki, T., Hashimoto, Y. \& Yabuuchi, E. (1989). Fluorometric deoxyribonucleic acid-deoxyribonucleic acid hybridization in microdilution wells as an alternative to membrane filter hybridization in which radioisotopes are used to determine genetic relatedness among bacterial strains. Int J Syst Bacteriol 39, 224-229.

Felsenstein, J. (1981). Evolutionary trees from DNA sequences: a maximum likelihood approach. J Mol Evol 17, 368-376.

Fitch, W. M. (1971). Toward defining the course of evolution: minimum change for a specific tree topology. Syst Zool 20, 406-416.

Jukes, T. H. \& Cantor, C. R. (1969). Evolution of protein molecules. In Mammalian Protein Metabolism, vol. 3, pp. 21-132. Edited by H. N. Munro. New York: Academic Press.

Kim, H., Choo, Y.-J. \& Cho, J.-C. (2007). Litoricolaceae fam. nov., to include Litoricola lipolytica gen. nov., sp. nov., a marine bacterium belonging to the order Oceanospirillales. Int J Syst Evol Microbiol 57, 1793-1798.

Kovacs, N. (1956). Identification of Pseudomonas pyocyanea by the oxidase reaction. Nature 178, 703.

Ludwig, W., Strunk, O., Westram, R., Richter, L., Meier, H., Yadhukumar, Buchner, A., Lai, T., Steppi, S. \& other authors (2004). ARB: a software environment for sequence data. Nucleic Acids Res 32, 1363-1371.

Mesbah, M., Premachandran, U. \& Whitman, W. B. (1989). Precise measurement of the $\mathrm{G}+\mathrm{C}$ content of deoxyribonucleic acid by highperformance liquid chromatography. Int J Syst Bacteriol 39, 159-167.

Saitou, N. \& Nei, M. (1987). The neighbor-joining method: a new method for reconstructing phylogenetic trees. Mol Biol Evol 4, 406425.

Stackebrandt, E. \& Ebers, J. (2006). Taxonomic parameters revisited: tarnished gold standards. Microbiol Today 33, 152-155.

Swofford, D. L. (2002). PAUP ${ }^{*}$ : phylogenetic analysis using parsimony (and other methods), version 4.0 Beta. Sunderland, MA: Sinauer Associates.

Wayne, L. G., Brenner, D. J., Colwell, R. R., Grimont, P. A. D., Kandler, O., Krichevsky, M. I., Moore, L. H., Moore, W. E. C., Murray, R. G. E. \& other authors (1987). International Committee on Systematic Bacteriology. Report of the ad hoc committee on reconciliation of approaches to bacterial systematics. Int J Syst Bacteriol 37, 463-464. 